\title{
The Relationships between Self-care and Coping Strategy among People Living with Human Immunodeficiency Virus
}

\author{
Kusman Ibrahim ${ }^{1 *}$, Desri Resnawati ${ }^{1}$, Laili Rahayuwati ${ }^{2}$, Yusshy Kurnia Herliani ${ }^{1}$, Nursiswati Nursiswati ${ }^{1}$ \\ ${ }^{1}$ Department of Medical Surgical Nursing, Faculty of Nursing, Universitas Padjadjaran, Bandung, Indonesia; ${ }^{2}$ Department of \\ Community Health Nursing, Faculty of Nursing, Universitas Padjadjaran, Bandung, Indonesia
}

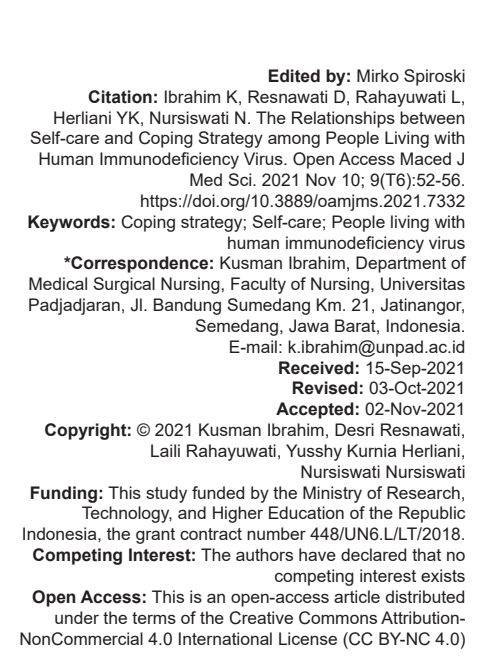

Abstract

AIM: This study aims to examine the relationships between self-care and coping strategy among people living with
human immunodeficiency virus (HIV) (PLWH). METHODS: A cross-sectional design involving 76 subjects of PLWH who attended the HIV clinic at a District Hospital in West Java Province, Indonesia. They met inclusion criteria such as being adult, has been living with HIV for over 1 year, and be able to communicate both verbal and written in Bahasa Indonesia. Self-care was measured by the 41-item Self-care Assessment Worksheet instrument, and coping strategies were measured by the 60-item Jalowiec Coping Scale. Pearson-product moment correlation was performed to examine the relationships between self-care and coping strategy scores.

RESULTS: The majority of respondents $(57.8 \%)$ used the emotion focused coping strategy such as supportant $(31.5 \%)$ followed by fatalistic $(21 \%)$ and optimistic $(17.1 \%)$ when they deal with stressful situations. Optimistic coping was reported as the most effective coping by the respondents. Nearly half of respondents $(42 \%)$ have intermediate self-care level which the highest number of self-care was medication. There was a significantly relationship between problem-focused coping strategy and the self-care scores $(r=0.378, p<0.01)$. Confrontive coping strategy has positive correlation with symptoms management $(r=0.264, p<0.05)$ and stress management $(r=0.280, p<0.05)$. Self-care information has positive correlation with palliative coping strategy $(r=0.281, p<0.05)$ and supportant coping strategy management $(r=0.236, p<0.05)$. Prevention and medication have positive correlation with optimistic emotional coping strategy $(r=0.264, p<0.05)$.

CONCLUSION: Understanding PLWH coping strategies could assist nurses to reinforce patient's positive coping strategies and change maladaptive coping strategies. Nurses could facilitate patients to develop a more adaptive coping strategies in enhancing self-care capability among PLWH.

\section{Introduction}

Human immunodeficiency virus (HIV) infection remains to be a major global public health issue. The World Health Organization (WHO) estimated that 38.0 million people worldwide were living with HIV at the end of 2019 [1]. Based on the WHO data for 2019 , there were $78 \%$ of new HIV infections in the Asia Pacific region. Although it tends to fluctuate, HIV cases in Indonesia continue to increase from year to year. During the last decade, the number of HIV cases in Indonesia reached its peak in 2019, with 50,282 cases. West Java Province reported 6066 HIV cases which constituted as the third highest number of HIV cases in Indonesia [2].

In 2019 , there were $68 \%$ of adults living with HIV globally receiving antiretroviral therapy (ART). However, not all people living with HIV (PLWH) have proper access to HIV testing, treatment, and care [1]. ART and symptom management have been regarded as effective ways to control the virus, reduce mortality rate, and improve quality of life. However, low access to
ART, and the presence of stigma, caused most PLWH experienced stressful life and physical problem [3].

HIVIAIDS causes negative impacts on physical, psychological, social, and spiritual aspects of human life. Therefore, people infected with HIV need a continuing of care, support, and treatment. PLWH experience severe psychological distress in response to family conflict, living bereavement, and other adverse psychological effects such as feeling depressed, feeling worried, anxiety, withdrawing and disruption of socialization, and despair which finally resulting stressful life due to negative issues and stigmatization [4]. Those problems can make stressful situation for PLWH which require adaptive coping strategies to confront and adjust with the situation [5]. Coping strategies can be defined as an individual's efforts to use cognitive and behavioral strategies to manage and regulate pressures, demands, and emotions in response to stress. People can develop either emotion or problem-focused coping (PFC) strategies [6], [7], [8].

On the other hand, advancement of HIV treatment has changed the nature of the disease from 
acute fatalistic to chronic manageable disease. Self-care has become a central issue to succeed management of a chronic disease such HIVIAIDS. Self-care refers to a range of activities to maintain health and well-being, it may include the fulfillment of nutrition, activity, and exercise, prevention and further transmission, treatment therapy, symptom management, information seeking and support, stress management, rest, and sleep [9]. Self-practice activities and coping strategies are the important aspect in comprehensive nursing care for PLWH. However, there is a little known about the relationships between self-care and coping strategies among PLWH. Understanding the relationships between self-care and coping strategies among PLWH is crucial to design a comprehensive nursing care for PLWH. This study aims to examine relationships between self-care and coping strategies among PLWH.

\section{Materials and Methods}

A cross-sectional descriptive analytical study was used as design of this study. Seventy-six respondents were recruited purposively from a hospital affiliated HIV clinic in West Java Province, Indonesia, to participate in this study. The inclusion criteria included being HIV positive for over 1 year, being adult, and able to communicate both verbal and written in Bahasa Indonesia. Self-care practice was measured by the self-report 41-item Self-care Assessment Worksheet (SCAW) instrument adapted from Norton (1996), whereas coping strategies were measured by the 60 -item Jalowiec Coping Scale (JCS). The questionnaires have been back translated into Bahasa Indonesia. The reliability of the Indonesian version was ensured and yield Cronbach alpha of 0.91 for the JCS and 0.75 for the SCAW. The validity of the content of the Indonesian version instruments was assessed by a panel of experts from Faculty of Nursing Universitas Padjadjaran resulted agreement of all items of the SCAW and the JCS.

The SCAW and JCS were self-administered questionnaires. Written informed consent was obtained on the subjects understood and agreed to voluntarily participate in this study. After completion the questionnaire, the subjects were given appreciation and souvenir. The instruments were checked for completeness, protection for confidentiality, and store in the computer with password access. Pearson's product-moment correlation was performed to examine the relationship between self-care and coping strategies variables. Ethical clearance for the study was obtained from the Research Ethical Committee of Universitas Padjadjaran with the number 366/UN6.KEP/EC/2018.

\section{Results}

Demographic data show that the majority of respondents were men and single with a mean age of 33 years. The majority of respondents had a job and graduated from senior high school. Almost half of the respondents contracted HIV through homosexual activity. Almost half of the respondents has been living with HIV and taking ARV for over a year.

Over half of the respondents use more frequently emotion focused coping (EFC) than problem-solving focused coping strategies when dealing with the stressful situation (Table 1). The most frequently used coping type by the respondent was supportant $(31.5 \%)$ followed by fatalistic $(21 \%)$ and optimistic (17.1\%), whereas optimistic coping was considered as the effective coping by majority of the respondent (92.3\%) (Table 2).

Majority of the respondent (55.3\%) have practiced self-care over the average of group score, which considered as good with regard to nutrition, exercise, prevention of further HIV transmission, stress management, taking medication, symptom management, and seeking information (Table 3).

Total score of coping strategy and its subscore of PFC strategy were positively correlate to total score of self-care practice $(r=0.25, p<0.05 ; r=0.378, p<0.01)$. Confrontive and supportant coping styles were representative from PFC group that showed having positive association with self-care score $(r=0.403, p<0.01 ; r=0.260, p<0.05)$. There was only optimistic coping style having significantly correlation with self-care score in the group of EFC strategy $(r=0.290, p<0.05)($ Table 4$)$.

\section{Discussion}

In this study, the coping strategies were explored as well as the effectiveness of the coping strategies in $\mathrm{PLWH}$. Coping strategies were defined as a way for a person to deal with a problem or situation they experience either as a threat or an obstacle [6]. Coping as a factor that can determine a person's ability to make adjustments to stressful situations, in regulating one's coping will affect the coping strategies that will be carried out in solving various problems [10].

The results of this study showed that the highest percentage of coping strategy used by PLWH was EFC. The result is congruent with previous studies that found most PLWH used EFC strategies [11]. EFC is the type of coping which plays a role in maladaptive behavior such as crying, eating a lot, and engaging in risky health behaviors such as drinking alcohol. 
Table 1: Percentage of coping strategies frequently used by the respondent $(n=76)$

\begin{tabular}{lcc}
\hline Coping strategies & $\mathrm{f}$ & $\%$ \\
\hline PFC & 32 & 42.2 \\
EFC & 44 & 57.8 \\
Total & 76 & 100 \\
\hline PFC: Problem-focused coping, EFC: Emotional-focused coping.
\end{tabular}

Meanwhile, PFC can be interpreted as adaptive coping, where someone uses the coping when facing stress or pressure [12].

Table 2: Effectivity of the coping strategies used by the respondent $(n=76)$

\begin{tabular}{|c|c|c|c|c|}
\hline \multirow[t]{3}{*}{ Coping strategies } & \multicolumn{4}{|c|}{ Effectivity } \\
\hline & \multicolumn{2}{|c|}{ Effective } & \multicolumn{2}{|c|}{ Not effective } \\
\hline & $f$ & $\%$ & $f$ & $\%$ \\
\hline \multicolumn{5}{|l|}{ PFC } \\
\hline Confrontive & 5 & 83.3 & 1 & 16.6 \\
\hline Palliative & 0 & 0.0 & 2 & 100 \\
\hline Supportant & 16 & 66.6 & 8 & 33.3 \\
\hline \multicolumn{5}{|l|}{$\mathrm{EFC}$} \\
\hline Evasive & 0 & 0.0 & 0 & 0.0 \\
\hline Fatalistic & 7 & 43.7 & 9 & 56.2 \\
\hline Emotive & 4 & 36.3 & 7 & 63.6 \\
\hline Optimistic & 12 & 92.3 & 1 & 7.6 \\
\hline Self-reliant & 3 & 75 & 1 & 25 \\
\hline
\end{tabular}

This study revealed that the highest type of coping used by respondents was supportant followed by fatalistic and optimistic. These three coping strategies were considered to be effective compared to other coping strategies. Supporting is a type of problem-solving focused on using the support system. The subjects seem to be more realistic in facing many challenges related to living with HIV.

Table 3: Percentage of self-care $(n=76)$

\begin{tabular}{lllll}
\hline Self-care item & \multicolumn{2}{l}{ Over the group mean } & \multicolumn{2}{l}{ Lower the group mean } \\
\cline { 2 - 5 } & $\mathrm{f}$ & $\%$ & $\mathrm{f}$ & $\%$ \\
\hline Nutrition & 41 & 53.9 & 35 & 46.1 \\
Exercise & 41 & 53.9 & 35 & 46.1 \\
Prevention of HIV transmission & 37 & 48.7 & 39 & 51.3 \\
Stress management & 37 & 48.7 & 39 & 51.3 \\
Medication & 52 & 68.4 & 24 & 31.6 \\
Symptom management & 42 & 55.3 & 34 & 44.7 \\
Information & 35 & 46.1 & 41 & 53.9 \\
Total self-care & 42 & 55.3 & 34 & 44.7 \\
\hline
\end{tabular}

Nevertheless, a small number of the participant had a fatalistic coping strategy characterized by a pessimistic attitude. Nurses can help people with

Table 4: Correlation between coping strategy score and selfcare score

\begin{tabular}{ll}
\hline Coping strategy & Self-care \\
\hline PFC & $0.378^{* *}$ \\
Confrontive & $0.403^{* *}$ \\
Palliative & 0.162 \\
Supportant & $0.260^{*}$ \\
EFC & 0.094 \\
Evasive & 0.027 \\
Fatalistic & -0.172 \\
Emotive & -0.062 \\
Optimistic & $0.029^{*}$ \\
Self-reliant & 0.180 \\
Total coping & $0.250^{*}$ \\
\hline${ }^{*} p<0.01 ;{ }^{*} p<0.05$. PFC: Problem-focused coping, EFC: Emotional-focused coping.
\end{tabular}

fatalistic coping preferences through activities with a focus on avoiding a hopeless situation. Many hopes should be described and bring PLWH into positive belief in their life. These supports are associated to prevent worsen stressful life in PLWH [13]. In general, support for PLWH from nurses and HIV team, family, and other informal caregivers was launched by the authorities toward religious-based information, communication, and education. However, positive coping was important in minimizing psychological distress [14].

The factors determine which strategy is often or widely used by a person depending on the person's personality, and the degree of stress from a condition, or the problems they face by looking at the effectiveness in overcoming the problem. The results of this study indicate that most of the respondents who chose the PFC type of coping were effective in overcoming the problem, while the effectiveness of the EFC type of coping was lower than PFC. An effective coping strategy must refer to five functional coping tasks, including reducing a very dangerous environmental condition and increasing the prospect of improving it; tolerate or adapt to negative reality; maintaining a positive self-image; maintaining emotional balance, and continued satisfaction with relationships with others [6].

The majority of participants have intermediate self-care (more than the average) which the highest number of respondents who perform intermediate self-care was medication. Meanwhile, nearly half of the respondents in this study were in the mediate care category (less than average) from the results obtained that there are still some PLWH who cannot perform self-care to maintain health. Self-care is an effective effort to reduce the spread of disease and burdens for HIV participants who have become chronic diseases and reduce AIDS-related mortality [15]. Maintaining and managing effective self-care can have a positive impact. When PLWH is unable to do self-care, PLWH experiences problems that cause severe stress, both from their illness and from their psychosocial impact.

The result of this study revealed that patients with higher use of optimistic emotional coping strategies were higher in performing good self-care of prevention and medication. Prevention is an effort made by PLWH to not transmit and reduce the increase in HIV infection. Efforts that can be made by PLWH to prevent transmission are eliminating bad habits in the past such as sexual intercourse with more than 1 partner, prevention using condoms when having sexual intercourse and not having blood contact with other people as blood donors [2].

Moreover, seeking information and support showed a positive relationship with palliative and supportant coping strategies. PLWH who perform palliative and supportant coping strategies were higher in performing information seeking and support related HIV. PLWH who get support from their closest people tend to do the treatment well. PLWH who get support and various information from their environment increase self-confidence, tend to eliminate feelings of helplessness, and affect their physiology and psychology [16]. 
From the results of the research in symptom management, almost all respondents had good efforts by always coming to health facilities such as clinics, public health centers, and hospitals that help deal with the symptoms or complaints they feel. This shows that there were several efforts that PLWH still do not know about managing their symptoms. PLWH needs to be empowered to manage symptoms, one of which is by doing self-care and seeking information related to the symptoms they are experiencing [17]. The previous study reported that efforts to manage symptoms with self-care are carried out by PLWH by relying on their own experiences, seeking information from health services, seeking help, and diverting feelings of symptoms by doing activities that make them comfortable [15]. On the other hand, maintaining adherence to antiretroviral treatment is also significant to minimize symptoms experience. A previous study in the same province where this study carried out reported that $40 \%$ of PLWH $(n=30)$ have low to moderate level of ART adherence [18]. In addition, fatigue was likely reported a common symptom among PLWH that correlated to the level of CD4 and blood hemoglobin [19].

This current study has several limitations as well as strengths. To the best of our knowledge, definitive conclusions on causality cannot be made, and further studies related to nursing intervention for coping strategy and self-care among patients with HIV may be necessary.

\section{Conclusion}

Based on the findings, EFC was the majority coping strategy used by PLWH which plays a role in maladaptive behavior. However, optimistic coping strategy as part of PFC was the most effective coping strategy which was interpreted as adaptive coping. Type of the used coping strategy will affect self-care. Confrontive coping strategies will affect symptoms management and stress management. Searching information has a positive correlation with palliative coping strategy and supportant coping strategy management. Meanwhile, prevention and medication have a positive correlation with optimistic emotional coping strategies. Understanding their coping strategies could assist nurses to reinforce patient's positive coping strategies and change maladaptive coping strategies. Nurses could develop a more adaptive selected coping strategy appropriate to enhance self-care among HIV patients.

\section{References}

1. World Health Organization. HIVIAIDS. Geneva: World Health Organization; 2020.

2. Ministry of Health of the Republic of Indonesia. Infodatin HIV AIDS. Indonesia: Ministry of Health of the Republic of Indonesia; 2020.

3. Lindayani L, Ibrahim K, Der Wang J, Ko NY. Independent and synergistic effects of self-and public stigmas on quality of life of HIV-infected persons. AIDS Care. 2018;30(6):706-13. https:// doi.org/10.1080/09540121.2017.1396282 PMid:29115159

4. Galuh M, Novani D. Pentingnya pengungkapan status hiv/aids odha pada orang terdekat. J Berk Kesehat. 2016;1(1):47-52. https://doi.org/10.20527/jbk.v1i1.661

5. Salami S, Muvira AA, Yualita P. Studi kualitatif strategi koping penderita HIV AIDS di kota bandung a qualitative study of coping strategies among people living with HIVIAIDS in Bandung. Faletehan Health J. 2021;8(1):22-30. https://doi.org/10.33746/ fhj.v8i01.243

6. Folkman S, Lazarus RS, Gruen RJ, DeLongis A. Appraisal, Coping, Health Status, and Psychological Symptoms. J Pers Soc Psychol. 1986;50(3):571-9. https://doi. org/10.1037/0022-3514.50.3.571

PMid:3701593

7. Sukartini T, Nursalam $\mathrm{N}$, Arifin $\mathrm{H}$. The determinants of willingness to care for people living with HIV-AIDS: A cross-sectional study in Indonesia. Health Soc Care Community. 2021;29(3):809-17. https://doi.org/10.1111/hsc. 13318

PMid:33639031

8. Nursalam N, Sukartini $T$, Arifin H, Pradipta RO, Mafula D, Ubudiyah M. Determinants of the discriminatory behavior experienced by people living with HIV in Indonesia: A cross-sectional study of the demographic health survey. Open AIDS J. 2021;15(1):1-9. https://doi. org/10.2174/1874613602115010001

9. Orem DE, Taylor SG. Renpenning, Nursing: Concepts of Practice. Britania Raya: Mosby; 2001.

10. Maryam S. Strategi coping. J Konseling Andi Matappa 2017;1(2):101. https://doi.org/10.31100/jurkam.v1i2.12

11. Silva RT, da Silva RA, Rodrigues ID, de Souza Neto VL, da Silva BC, de Lima Costa Souza FM. Estratégias de enfrentamento utilizadas por pessoas vivendo com aids frente à situação da doença. Rev Lat Am Enferm. 2018;26:2985. https:// doi.org/10.18471/rbe.v32.26065

12. Hidayanti E. Strategi coping stress perempuan dengan hiv/aids. Sawwa J Stud Gend. 2013;9(1):89-106.

13. Tang $X$, Wang HY, Wang M, Ren XH, Jiang FR, Li JL. Structural equation modeling analysis of social support, coping strategies, depression and suicidal ideation among people living with HIVIAIDS in Changsha, China. Neuropsychiatr Dis Treat. 2018;14:2923-30. https://doi.org/10.2147/ndt.s177460 PMid:30464476

14. Verstraaten EJ, Beeren FM, Janssen JL, Kemper S, Siregar AY Tromp N, et al. Radboud Repository of the Radboud University Comparative Cost Analysis of Four Interventions to Prevent HIV Transmission in Bandung, Indonesia. Indones J Intern Med. 2020;49(3):236-42.

15. Musheke M, Bond V, Merten S. Self-care practices and experiences of people living with HIV not receiving antiretroviral therapy in an urban community of Lusaka, Zambia: Implications for HIV treatment programmes. AIDS Res Ther. 2013;10(1):1-13. https://doi.org/10.1186/1742-6405-10-12

PMid:23675734 
16. Jambak N, Wahyuni A. Faktor-faktor yang mempengaruhi perubahan perilaku pasien HIVIAIDS. J Mutiara Ners. 2018;1(1):1-10. https://doi.org/10.32883/hcj.v1i2.5

17. Safitri EA, Dewi YI. Pengalaman perempuan dengan HIVIAIDS dalam menjalani pengobatan. J Online Mahasiswa Progr Stud IImu Keperawatan Univ Riau. 2015;2(2):8719.

18. Alfian A, Ibrahim K, Rafiyah I. The effect of the E-patuh application on HIV/aids patients' adherence in consuming antiretroviral. J Keperawatan Padjadjaran. 2019;7(1):49-57. https://doi.org/10.24198/jkp.v7i1.809

19. Ibrahim K, Kurnia HY, Rahayuwati L, Nurmalisa BE, Rifa'atul Fitri SU. Hubungan antara Fatigue, Jumlah CD4, dan Kadar Hemoglobin pada Pasien yang Terinfeksi Human Immunodeficiency Virus (HIV). J Keperawatan Padjadjaran. 2018;5(3):271-80. https://doi.org/10.24198/jkp.v5i3.649 